\title{
Social Relations, Science, Education, Lifestyle and Social Life in the Historical and Philosophical Heritage of the Khorezm Mamun Academy
}

\author{
Masharipova Gularam Kamilovna \\ Professor of the Tashkent Institute of Textile and Light Industry
}

\begin{abstract}
In the historical and philosophical heritage of the scientists of the Khorezm Academy of Mamun, issues of social relations, science, education, lifestyle and social life are scientifically analyzed. It consists in identifying the influence of the natural science heritage of the scientists of the Khorezm Academy of Mamun on the development of socio-philosophical thinking, substantiating its significance in the history of philosophy, its place in the development of modern philosophy and its role in the development of philosophy. creation of new knowledge.

Keywords: academy, science, education, secular, religious knowledge, social life, social relations, development, classification of sciences, history of philosophy, modern philosophy.
\end{abstract}

\section{INTRODUCTION.}

The natural scientific views of the scientists of the Khorezm Academy of Mamun were studied by many specialists, scientists in this field, the monographs of V. Bartold [15], B. Rosenfeld [43-46], A. Khalidov [57] became an important methodological base.

A number of studies devoted to the teachings of the Khorezm Academy of Mamun as a whole have been published by foreign scientists. In particular, L. Rodet [60], G. Rudolph [61], A. Sayili [62], G. Sarton [65], F. Sezgin [66], M. Simon [67], H. Zuter [68 ]], J. Wallis [69], E. Wiedemann [70-71] monographic research devoted to the evolution of the teachings of Central Asian thinkers and natural, scientific and philosophical essence, to some extent reveals such problems as the genesis of sociology. -philosophical views on a subject that is important in the country.

Among the scientists of the Commonwealth of Independent States - B.A. Rosenfeld [42-46], H.F. Abdulla-Zade [9], A.A. Semenov [47], B.V. Lunin [35], M.M. Rozhanskaya [42] and others studied the heritage of the scientists of the Khorezm Academy of Mamun on various aspects of the heritage.

Scientists of our country I. M. Muminov [40], M. M. Khairullaev [56], A. Akhmedov [14], P. G. Bulgakov [19-21], G. P. Matvievskaya [36-37], B. Abdukhalimov [10], S. Karimova [32], Kh. Khikmatullaev [59], A.D. Sharipov [52-53], T. Usmonov [49], J. Ibodov [25-26], R.Bakhodirov [16], Masharipova G.K. [38,39] and others have conducted research.

In order to clarify the essence of the article as a primary source, it was found that the problems left a deep mark in the works of Arabic and Persian manuscripts, one of which is the manuscript of the third series of books of Abu Ali ibn Sina "Kitab al-Shifa" on mathematics, this work "Usul 'Ilm al-Geometry' was published in Cairo in 1976. It was translated from Arabic into Uzbek by the author with comments and used in the work. The Arabic version of the manuscript of Nasir ad-Din at-Tusi edited by Usul li-Uklidis is kept in the Manuscript Fund of the St. Petersburg Branch of the Russian Academy of Sciences under number 49/672. The work was published in 1594 in Rome. Some of them have been translated by the author with comments. The theorem of

ISSN: 0010-8189

(C) CONVERTER 2021

www.converter-magazine.info 
Nasir al-Din at-Tusi on the theory of parallels, which is relevant to this subject, is studied in detail in a copy published in Tehran in 1881 by Nasir al-Din at-Tusi "Foundations of the theory of Tahrir Uklidis fi 'ilm al-geometry. The theory of parallels was compared with the scientific research of Abu Ali ibn Sino, one of the scholars of the Khorezm Academy of Mamun. The work of Muhammad ibn Umar Fakhriddin ar-Razi "Jome al-Ulum", dedicated to the Khorezm king Aloviddin Muhammad (1200-1220), was used in the library of the Uzbek scholar H. Siddikov and translated from Arabic into Uzbek [75]. The views of Fakhriddin al-Razi on the classification of sciences are scientifically analyzed. Copies of the work of Mahmud ibn Muhammad ibn Umar alChagmini "Mulahhas fi-l-hay'a" in the manuscript collection of the Abu Raikhan Beruni Institute of Oriental Studies of the Academy of Sciences of the Republic of Uzbekistan No. 10417, 7761/3, $8796 / 11,11599 / 3$ were translated by the author into Uzbek language, translated and distributed [76]. The scientific heritage of Mahmoud ibn Muhammad ibn Umar al-Chagmini was studied on the basis of sources, and it was found that this work served as a textbook for later scholars and European countries. Hajaj ibn Yusuf ibn Matar (late 8th century - early 9th century) "Kitab Uklidis fi-1-Usul". The treatise of Hajjaj ibn Yusuf ibn Matar was compared with the Uzbek translation of manuscript no. 2145, kept in the Russian Academy of Sciences in St. Petersburg, and the commentary of Khorezm scholars on Euclid's "Foundations" in the field of geometry. ... Nasir adDin at-Tusi's book "Majmua ar-Rasul" was published in Hyderabad, India in 1358/1939, from which some information was obtained by Nasir ad-Din at-Tusi on the substantiation of the sciences. The manuscript of the book of Abu Ali al-Hasan ibn Haris al-Khububi "Kitab al-iksa 'wa-t-tajnis fi' ilm al-Hisab" was translated by the author into the Uzbek language and translated into the Khorezm scholar Muhammad ibn Musa al-Khwarizmi al-Hisab ... questions of mathematics were compared [79].

Abu Ali ibn Sina's manuscript No. 2385/22 Qunuz al-Ma'rifa [80] and Manuscript No. 3374/5 Ganj al-Ma'ruf [81] were translated by the author, and the views of Abu Natural sciences Ali ibn Sina and his philosophical views have undergone deep scientific analysis. Also Mahmud ibn Muhammad ibn Umar al-Chagmini "Al-mulahas fil haya" 10417; 7761/3; 8796/11; Manuscript number 11599/3 [82] Ash-Sharh Mahmud ibn Muhammad ibn Umar al-Chagmini "Al-mulahhas fi1-haya" Manuscript No. 2655 [83] "Sharh al-moolahhas fi-l-haya" 8217, 3935 units of digital manuscripts, a total of 20 manuscripts have been studied and scientifically analyzed by the author. Information was used from the manuscript of Hussein ibn al-Hasan al-Khwarizmi al-Kubrawi No. 1207/3 "Nuzhat al-mallok fi Hayat al-aflok" [84]. Some parts of the manuscript No. 2385/32 of the book of Abu Nasr al-Farabi "Risala fi mo yasuh va molo yasuh min ahkom an-nujum" [85] were translated by the author from Arabic into Uzbek. area of exact sciences.

\section{MAIN BODY.}

His research on the influence of socio-philosophical thought on the development of special research in the field of philosophy has a certain scientific and theoretical significance in the study of the problem within the subject.

The above classification of studies shows that:

First, the study examines the historical and axiological aspects of the heritage of the scientists of the Mamun Khorezm Academy as a whole;

ISSN: 0010-8189

(C) CONVERTER 2021 
Secondly, there was no comprehensive scientific research of the scientific heritage of the scientists of the Khorezm Academy of Mamun, in particular, the influence of their natural science heritage on the development of social and philosophical thinking.

According to Abu Raikhan Beruni, the character and spiritual views, the image and vision of a person are formed under the direct influence of the environment. After all, it is this natural environment, geographical conditions that can become an important basis for the formation of peoples and nations. "Man has a complex body by nature. The human body consists of opposite parts, which are united by the power of submission "[23, p. 40-43]. According to Beruni, all people have similarities, but at the same time, different aspects. Over time, phrases multiplied, were remembered and, as a result of repetition, were formed and organized "[23, p. 40-43].

Abu Ali ibn Sina said: "Man differs from all other animals in his speech, language and thinking. The human mind is enriched by the study of various sciences "[24, p. 59].

According to Abu Nasr al-Farabi, a person by nature needs other people to organize, strengthen and improve his life. Nobody can do it alone. "A person is such a being that he can only satisfy his needs in society and rise to a higher spiritual level" [51, p.69]. A person should be an architect and creator of his life, cultivate in himself noble qualities and talents.

Everyone is in constant contact with other people, different social groups: family, production team, is a member of the nation. He lives in close contact with other people. All human activity is carried out within the framework of social relations inherent in this society, including: political, legal, economic, moral and other relations, the totality of social relations that make up the essence of a person is changing. It follows from this that both the formation of certain human qualities and the development of society depend primarily on material production, and not on the geographical environment, and that only when analyzing the historically changeable nature of human production can we talk about how certain natural conditions affect certain social conditions. processes. At the same time, a person always acts as an active participant in the interaction of nature and society. The property of the natural environment is determined not by the property of the social environment, but by the property of the social environment. In this sense, people regulate their metabolism with the help of nature, taking it under their general control, thereby not allowing the blind forces of nature to dominate them [54, p. 252].

In the development of moral thinking in the Muslim region of the Middle East, a special place was given to the famous pandnoma, which explains the essence of morality and promotes morality works of art and didactics widespread among the people. What they have in common is the transmission of ethical norms, principles and factors of moral culture to the masses in understandable colorful forms. The science that studies these moral phenomena from the point of view of the theory of relativity and relativity is called ethics. This is an ancient science with a history of several thousand years, which we call "Science", "Science of morality", "Science of morality", "Ethics". Ethics studies the origin and essence of morality, moral relations of a person in society. Morality is the plural of the Arabic word for "behavior", a historically established set of stable, specific norms and rules that govern behavior, relationships, the interaction of people in social and personal life, as well as their relationship with society. The term "morality" has two different meanings: while as a general concept it refers to the object of study of science, as a specific concept it refers to the most comprehensive part of human behavior and behavior. It is well

ISSN: 0010-8189

(C) CONVERTER 2021

www.converter-magazine.info 
known that morality is a trait inherent in human nature and behavior that manifests itself without undue stress. For this reason, human morality is, in a sense, innate and can only be purified if it is protected from evil vices. In turn, good behavior and relationships are assessed as moral, and negative ones as immoral.

Medieval encyclopedists Abu Nasr al-Farabi, Abu Raikhan al-Biruni, Abu Ali ibn Sina and Mahmud al-Zamakhshari worked in the theoretical and practical areas of ethics. Abu Nasr al-Farabi divides philosophy into two parts - theoretical and practical, and the scientist includes ethical issues in practical philosophy. Ethical issues are raised in his works, such as "A Book Indicating the Way to Happiness", "On the Achievement of Happiness", "The Wisdom of a Statesman", "The City of Noble People." In them, the main problem is human happiness. Abu Nasr al-Farabi also dwelled on the problem of life and death. According to him, a person must be mature in order to do good deeds in life. A character's kindness and maturity is determined by the fact that he is standardized in human behavior. On the other hand, etiquette is described by the thinker as a moral phenomenon that adorns the condition of the rich and steals poverty from the poor. Indeed, morality reflects social necessity, needs and interests of society and is expressed in the form of accepted norms and habits, requirements and values, supported by public opinion [50, p. 41].

Abu Raikhan Beruni is one of the great thinkers and geniuses of his time. He thoroughly mastered all the sciences of his time, primarily astronomy, physics, mathematics, theology, mineralogy. Thanks to his contribution to the development of these sciences, his name became one of the great figures of world science. "Beruni thought with great objectivity and truthfulness in scientific matters, as well as in the assessment of historical events and his contemporaries" [30, $p$. 42].

Beruni took a position close to deism in his philosophical views. He argued that God is the creator, giving nature the right to preserve and develop this divine power of the first impulse. He puts forward the idea that existence is ancient and eternal, and that the three elements - fire, air and earth - also come from the element of water. In his philosophical views, Aristotle argued that the argument of many philosophers that "other worlds exist" [27, p. 18] is unfounded, he wrote. When a scientist talks about the eternity of the material world, he asks the question of how time is measured and answers it with the motion of the planets.

According to Beruni, there is nothing but God and primordial matter. A natural question arises, how then is time measured? Probably, at that time, seconds were equal to a large amount of time. The logic of Beruni's reasoning leads to the conclusion that dimensionlessness, eternity of time, the world was created outside of time. Reflecting on the relationship between matter and form, he says: "... motion by its very nature belongs to matter and makes the soul travel in various forms.

So, matter is active, and everything that belongs to it helps it move. " Beruni's matter consists of concreteness, which manifests itself in one way or another. And existence is constantly changing and developing. This is the power of nature.

The philosopher considers experience and logic to be an important means of knowing experience and logic and the criterion of truth. According to him, the beginning of cognition comes from the senses, and in the process of cognition, feelings acquire great importance. Beruni explains that the process of perception is specific to two parts of nature - animals and humans, perception is associated with consciousness, and the aspects that connect them are the senses of perception and

ISSN: 0010-8189

(C) CONVERTER 2021

WwW.converter-magazine.info 
vision. Beruni says that reason, which is the highest level of knowledge, is given by God. His mission is to know the world, and his ultimate goal is to use it for the benefit of people without prejudice to the harmony of nature.

The spiritual heritage of Abu Raikhan Beruni, the value of his works, the scientific significance of his views lies in the fact that he provides historical information about the high level of national and religious tolerance on the territory of our country and our people located on the Great Silk. Road. For example, Beruni noted in his works that thousands of years ago in the city of Urgench there were Jewish quarters, Christian churches, separate quarters where Arab, Indian, Chinese, and Slavic peoples lived together. Beruni emphasizes that people are organized into society to help each other, create what is necessary for marriage, avoid any disasters, be partners, sympathizers, sympathizers and live in safety. The main reason for the formation of human communities is mutual assistance, compassion and solidarity. At the same time, Beruni, as a humanist thinker, shows that this situation and order were later violated as a result of various robberies and military actions. For example, Beruni writes in Mineralogy: "Human needs are so diverse that he cannot satisfy them alone. Not a single assistant is enough to satisfy them. The needs are varied and many. They can only be satisfied by a team of several people. For this, people need to build cities "[4, p. eleven]. In his work "Geodesy" the scientist states the following: each of its participants will be in a state of mutual support, engage in work that will meet the needs of him and others "[6, p. 83]. This article presents a scientific analysis of the views of Abu Raikhan Beruni in the field of religion. Researchers A.B. Kholidov and B.T. Erman say: "Religion is given a broad meaning based on the views of that time, and it means the whole complex of spiritual life and even many areas of a person's practical life" [57, 47-p.].

According to A. Irisov, a major researcher of the philosophical views of Abu Raikhan Beruni, in the preface to the book "India": If they are in this sense, then they are absolutely right "[58, p.96].

When Beruni thinks about the meaning of human life, the goal of life is to achieve happiness, that is, to cognize and acquire knowledge. The scientist's worldview, his philosophical and moral views on society as a whole are a vivid example of medieval humanity.

This attitude towards nature is mostly sweet. avv. It was formed by the middle of the first millennium and changed significantly with the advent of theoretical thinking. This thinking has become an integral and integral part of philosophy, which arose at that time as a separate historical form of worldview. The first ancient philosophers strove to study nature in order to find an answer to the question of what is the main task of philosophy, the world, which they understood as space.

\section{THEORETICAL BACKGROUND.}

It is known that in the 7th-9th centuries in the Middle East, almost all of Aristotle's works were translated into Arabic and commented on, many of his ideas were accepted. During the Renaissance, the prestige of Aristotle in the East was so high that Aristotle is definitely mentioned when it comes to important natural science and philosophical issues. By this time, it was impossible to imagine the study of philosophy and the acquisition of worldly knowledge without getting to know Aristotle and his ideas. Thus, Eastern Aristotelianism (peripateticism) began to form and develop. The essence of the concept of "Eastern Aristotelianism" is that it represents not only the philosophical system or the teachings of Aristotle, but also rationalism, firmly associated with

ISSN: 0010-8189

(C) CONVERTER 2021

WWW.converter-magazine.info 
natural philosophy, and through it, and medieval rationalist philosophy. It should be noted that "the question of the spread of the Greek philosophical heritage in Central Asia has not received an answer, there are aspects that require clarification. In particular, there is no unambiguous answer to the question of how the culture of antiquity first spread in the East, and not in the West. In such conditions, the countries of the Baghdad Caliphate became the heirs of an ancient culture "[52, $p$. 44-45].

The social factors that created the conditions for the development of secular knowledge should be explained by the constant struggle of the peoples oppressed by the Arabs against Islam, the spread of the achievements of Indian, Central Asian, Iranian and especially Greek scientific thought. , which made possible the development of secular sciences [18, 111 -b.]. It should be noted that the Caliph Harun ar-Rashid tried to create a unique scientific and cultural center with a large library and astronomical observatory [10, p. 236], but during the reign of the famous caliph Mamun, the House of Wisdom (Bayt ul-Hikmah and its heyday (813-832) coincided with the following periods.

The disputes between Buruni and Ibn Sina did not arise by chance. Practically in all of Aristotle's works, especially in Metaphysics, Physics, On the Sky, On the Origin and Disappearance, Meteorology and others, there are historical sources about the correspondence of not only Eastern thinkers, but also his compatriots. The period of the first revival is rich in historical events and is interpreted as an important period in the history of Central Asia. The uniqueness of this period, strong socio-political and ideological processes in it, in particular, the social environment of Khorezm, Samarkand and Bukhara, spiritual life, the development of science, the creation of the Khorezm Mamun Academy were created by other peoples. Central Asia, the Middle East found expression in the generalization and further development of rich scientific and cultural traditions. The industriousness and ingenuity of the peoples of Central Asia led to the creation of prosperous oases, the construction of large cities with magnificent architecture, the development of crafts, the expansion of international trade through caravan, river and sea routes, and the economic development of the East. and the West, the revival of political and cultural ties, centuries-old religious and socio-philosophical traditions of public life, the rapid development of relations between different social groups and their settlements, the formation of science and culture and the development of scientific thinking. the necessary historical foundation.

Beruni and Ibn Sina used the dialectical method, one of the methods of scientific knowledge, in the course of their heated debates. From the first question of Beruni Ibn Sine, we see that he was skeptical about his cosmological theory. Beruni's questions about the weight and lightness of the celestial sphere, the absence of linear motion in it, the motion of matter and the theory of gravity of the body aroused interest. In Ibn Sina's scientific views on the universe, "circular motion" is recognized as an alternative form of "linear motion." According to Ibn Sina, the movement of the body in a "straight line" is a forced movement caused by some external force. Therefore, this movement is contrary to "natural movement". Movement and matter are not exactly the same phenomenon. Ibn Sina considers matter to be a phenomenon in a static state. Movement, according to Ibn Sina, is a constant and gradual change in the state of the body. On the other hand, this state of the object is the movement of the object towards the object, which can adapt to it in a neutral state, and not in an active state. According to the cosmological theory of Aristotle, the linear motion of an

ISSN: 0010-8189

(C) CONVERTER 2021 
object is associated with the movement of the object up and down, that is, the movement of the Earth and the Universe from the center or to the center, and their essence is the same. If the object moves upward, then this body will be a body formed by fire or air from their elements. If an object moves downward, it is considered to be composed of water and soil or their elements.

From Beruni's questions, we can say that he was skeptical about Aristotle's views on the round shape of celestial bodies. The famous astronomer G. Jalolov, who deeply studied this issue, noted that "Beruni's opinion was confirmed only after several centuries" [29, p. 122-134].

It is noteworthy that this supports Beruni's point of view that celestial bodies are spherical. Beruni emphasizes Aristotle's views on fire, in particular, on the formation of fire as a result of the interaction of heavenly bodies with air. Ibn Sina states in his responses that most philosophers support this idea of Aristotle. Fire is a form of separate matter that does not arise in a generally recognized way. He has a different nature. Ibn Sina notes that the idea of Beruni's fire was also put forward by the ancient Greek philosophers Miletus (seventh century BC), Heraclitus (fifth century BC) and Anaximenes (sixth-seventh centuries BC). We know from the history of philosophy that Aristotle criticized their views on fire. Since fire, air and water cannot arise from each other gradually as the substantial basis of existence and its universal elements. This question, according to Beruni, raises the question about the nature of things and events, about what their determinants consist of, about the existence of a transition of things from one qualitative state to another qualitative state on substantial grounds, substantiates his opinion about division into small particles. Ibn Sina does not accept Beruni's point of view, but supports Aristotle's idea that the primary matter of any object or body, its substance, changes its form and takes on a different form as the main reason for the fundamental quality and change of things and events. In other words, qualitative changes in things are, first of all, their transition from one formal state to another. Here we are witnessing a philosophy of form and content recognized in other works of Aristotle.

In philosophy, methods and methods of cognition of the Universe have been developed, which are reflected in the methodology (the doctrine of methods). In social philosophy, the ways and means of studying man and society are considered [31, p. 5]. Abu Raikhan Beruni emphasizes that the worldview was formed as a result of an evolutionary process. "Supports the idea that the source governing the Universe is the" structure and decay "contradiction" [2, p. 26]. At the same time, Beruni argues that the force that leads the world to social development is not contradictions and contradictions, but compromise and consensus at different social levels. "How can an apparent contradiction be believed?" [2, p. 99] the great thinker points out the growing need for change in conflict-free processes. Observation also plays an important role in the work of Beruni [38, p. 241]. Observation in the scientific study of nature is interconnected with other forms of knowledge. According to Beruni, the observer perceives the observed phenomenon in the place where it occurs [3, p. 57]. Consequently, observation fixes this or that event in its specific form [3, p. 57]. Old observational data can significantly distort the actual characteristics of the object. Beruni notes that the experiment conducted by the researcher and its results are reliable in practice. He writes that "there is no priority program except testing, there is no program that leads to success except testing in practice" [3, p. 57].

In conclusion, fundamental research on the scientific and philosophical heritage of Beruni and Ibn Sina continues. However, their attitude to theoretical issues of philosophy, geometry,

ISSN: 0010-8189

(C) CONVERTER 2021

www.converter-magazine.info 
astronomy, physics and other sciences that have not lost their relevance in our time is an important scientific and practical source in the history of science of New Uzbekistan, written in the title. Beruni and Ibn Sino.

In general, similar ideas can be found in the works of representatives of ancient Indian and Chinese philosophy. They believed that one should try to know the general laws of nature, and not resist them and obey them, because man is not able to change them.

Abu Ali Ahmad ibn Muhammad ibn Yakub ibn Miskawayh is a famous historian and educator. The book of a scholar who has studied Muslim countries, "On the Experience of Nations" contains valuable historical information. His brochure, Jovidoni Khurd, reflects his enlightenment and moral views.

In the course of our research, we paid special attention to the study of the works of scientists from the Khorezm Academy of Mamun, which are kept in the Manuscript Fund of the Institute of Oriental Studies named after Abu Raikhan Beruni of the Academy of Sciences of Uzbekistan. ...

Jovidoni Khurd Page No. 2213/11 29a - 64b, copy 1344, in Arabic. An excerpt from a work translated from Pahlavi into Arabic (Eternal Thought). It consists of 6 sections on ethics:

1. Wise thoughts and instructions of the Persians.

2. Exhortations of the Hindus.

3. Wise thoughts of the Arabs.

4. Wise thoughts and admonitions of the Greeks.

5. Advice from contemporary philosophers to the author.

The moral parts of this work were translated by Gaybullah al-Salam and Hamidjan Hamidi.

6. "Tajarib al-umam" (tjaryb (20) ("Book of the experience of the peoples") 41, part III, copy 1199, p. 227; No. 3388, part VI, p. 122.

The brochure is dedicated to the history of Muslim peoples (from ancient times to the 10th century) and is dedicated to the Persian land, the author's native land. He describes the rise of the Sassanid period. The play also provides valuable information on the history of the collapse of the Abbasid dynasty, the treasury and the tax system. Official documents were widely used.

Manuscripts of the book have been found in Amsterdam, Oxford, Paris and Istanbul. They were studied by I. Krachkovsky, V. Ivanov, A. Schmidt. In 1906, in the Hagia Sophia library in Istanbul, Professor H. Horowitz discovered a six-volume copy of this work, rewritten in 1111-1112.

Ibn Miskawayh believes that historical science unites human thinking and teaches us to understand what is happening and find the right path in various situations. The historian's task is to tell a story about how people behaved in a given situation, given that history consists of a system of events in which each process is repeated. Therefore, he sees in young people a perfect knowledge of history, invaluable in everyday life and big politics, enriching their worldview [11, p. 22].

Another great scientist and poet who worked in this school was Abdumalik ibn Muhammad ibn Ismail as-Saalibi an-Naysaburi. Abu Mansur al-Salibi was born in 961 in Nishapur, where he received his primary education. From a young age he liked to talk with many scientists and poets of the city. The sponsors were Allomagaamir and the poet Abu-l-Fadl al-Mikali. Salibi was also involved in trade. Thanks to this, he was able to visit many countries. For example, in 992-993 Saoliby came to Bukhara. In this city, he is also in the circle of scientists, makes many friends and participates in poetry readings. After a while, the scientist went to the palace of Khorezmshah

ISSN: 0010-8189

(C) CONVERTER 2021 
Mamun. Saalibi writes about the reasons for his visit to the palace of Khorezmshah and about his work there: The stay in the palace of the Khorezmshah Abu-l-Abbas positively influenced the author (Saalibi), he was inspired by the actions of the emir and made the manuscript worthy of his library "[1, p. 36].

Salibi was also sponsored by Abu Mahmoud Muzaffar Nasr ibn Sabuktegin, brother of Sultan Mahmud. Alloma died in 1038 in Nishapur.

Saalibi's books:

1. Kitab al-Ijaz wa'l-Ajaz (The Book of Remarkable and Permissible Points) "1848/1 Pages $1 \mathrm{~b}-25 \mathrm{a}$, copied in 1227 . The work consists of admonitions of rulers, statesmen in poetic and prosaic form.

2. "Kunz al-kuttab" ("Treasure of books") No. 1848 / II, p. 26b - 118b and "Kitab almuhodara" ("Book of lectures") No. 1848 / III, p. 119b - 193b. copied in 1727. The work is dedicated to secretaries. To facilitate the fulfillment of the strict requirements imposed on them, alSaalibi systematized passages from the works of various poets that could be used in official documents copied in 1727.

It consists of articles, parables, and instructions on missionary topics. According to the preface, it is dedicated to Djurjan and Kobus Vushmagir, the ruler of Tabaristan.

Abu Sahl Isa ibn Yahya al-Masihi al-Jurjani (970-1011) was a doctor born in Jurjan, educated in Baghdad, and the teacher of Ibn Sina. His most famous work is the Commentary, written for the library of Mamun ibn Mamun. He is also the author of One Hundred Issues on Medicine, Booklet on the Soul, Collection of Christian Booklets and Book on Nature.

Abu Sahl is a great scientist with a special place in the Christian Academy of Mamun, an enlightened and moral heritage. There is no doubt that his wisdom will be a close companion in the noble work of our youth, such as building a happy future, and will play an important role in achieving their goals.

At the time, religious beliefs were an extremely sensitive issue. For this reason, disagreements and disputes arose between different rulers and great statesmen. But the peculiarity of the Mamun Academy was that besides Muslims, there were also representatives of other religions. This suggests that an atmosphere of internationalism and friendship reigns in science.

Abu Nasr ibn Iraq played an important role in the development of mathematical sciences in the Khorezm Academy of Mamun. According to Abu Raikhan al-Biruni, Abu Nasr ibn Iraq was the first to introduce the muganni form into the musallasati qurrawi "solution".

Abu Nasr ibn Iraq wrote several treatises on astronomy, geometry and mathematics, 12 of which are dedicated to Abu Raikhan al-Biruni. These works are as follows [28]:

1. Kitab al-Sumut (Book of azimuths).

2. "Kitab fi' illati tansif at -tadil 'indaashab al -Sind”" (ktạb fy 'lë tnṣyf ạlt dyl 'nd ạ̉ṣhạb lsnd ) ("A book on why the equation is divided into two equal parts").

3. The book about "Kitab fi tashikhi kitab Ibrahim ibn Sinan fi tashihi ikhtilaf al-kawakib al'ulwiyya").

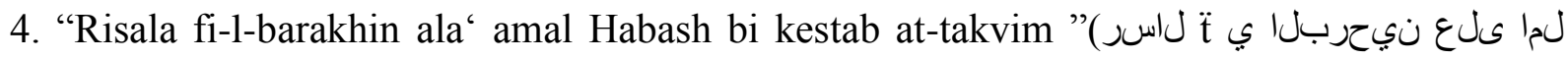

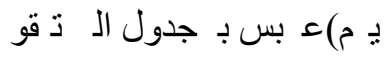

5. Brochure "Risala fi tasxihi mo waqa'a li-Abu Ja'far al-Hazin min as-sahvi fi zij as-safoyihi"

ISSN: 0010-8189

(C) CONVERTER 2021

Www.converter-magazine.info 
6. "Risala fi majazat dawair as-sumut fi-l-asturlab"

7. "Risala fi table ad-dakaik" (قاقدلا لودج يف a ل لاسر) ("Treatise on the table of minutes").

8. Brochure about Risala fi-l-barashini "ala 'amal Muhammad ibn as-Sabbah fi imtihan ashshams").

9. "Risala fi-d-dawair allati tahuddu as-sa'at al-zamaniyya"

10. Risala fi-l-burkhan 'ala' amal habash fi matali 'as-samt fi zijiksi "").

11. "Risala fi marifat al-qasii al-falakkiyati bitarikin gaira tarikin ratsal muallafati"

12. "Risala fixall subha 'arada lakshu fi-1-makalaas-shalasa' ashara min kitab" in the thirteenth [chapter] of the treatise on the resolution of doubts).

According to the famous European historian of mathematics K. Zachau (1845-1930) and the German historian M. Krause (1909-1944), the work of Abu Nasr ibn Iraq "Al-Majisti al-Shahi" ال شهي (neewteb ymedacA numaM eht ta nettirW numaM .hahsmzerohK ot detacided saw 997-1010. Menelaus's book on the Spheric was also written in the years 1007-1008, which indicates that it was written at the Academy of Mamun. This manuscript is kept at Leiden University under number 989.

In 1017, Abu Nasr, together with all the scientists of the Mamun Academy, went to Ghazna with Abu Raikhan Beruni. Although little is known about his life during this period, Abu Nasr wrote the following works in mathematics and astronomy:

1. "Risala fixall shubksa 'arada laxu fi-1-makalaas-Salisa' ashara min kitab al-Usul" treatise on the resolution of doubts in the thirteenth [chapter] ").

2. "Islax kitab Menelaus fi-l-kuriyat" (J ạ̣ ktạb mnạlạyạ fy lkryë) ("Menelaus" Spherica "siga sharhi").

3. "Kitab fi kuriyas-sama" (ktub fy kri k ạlsmạ) ("Booklet about the celestial sphere"). The manuscript of this work is kept in the Patna Library under No. 2468/22.

4. Tahzib at-Taalim (Tkhdaib at-Taalim) (mathematics education).

5. "Risala fi answer Masail al-Khandasa" (اسدنملا لاسم بوج بي تراسر) ("A treatise on answers to some questions of geometry"). The manuscript of this brochure is kept at Patna under No. 2468/19.

6. "Risala fi san'al-asturlab bi-t-tarik as-sina'i ila Abu Abdalaks Muhammad ibn 'Ali alMamuni" Treatise of Abdullah Muhammad ibn Ali al-Mamun on proposals for the construction of asturlabs. method of art ") and a number of similar works in Patna 2468/9, 2468/10, 468/11, 2468/12, 2468/13, 2468/14, 2468/15, 2468/16, 2468/17. , 2468/18, 2468/19, 2468/20, 2468/21, $2468 / 22$ - stored in the room.

Umar Khayyam evaluates the work of Abu Nasr in the field of mathematics and astronomy as follows: "Abu Nasr ibn Iraq is the greatest scientist in the field of mathematics" [41, p. 313].

Mustafa ibn Abdullah Kotib Halabi Haji Khalifa (1609-1657) in his book "Kashf az-zunun fi asami al-qutub wa-l-funun" Spherika ":" The first scientist who worked on this work of Menelaus was Muhammad ibn Isa Abu Abdullah al-Mahani (IX century). The famous mathematician of his time, Abu Fazil Ahmad ibn Abu Said Hirawi, faced this problem for the second time. The work begun by him remained unfinished. Amir Abu Nasr Mansur ibn Iraq is a scientist who completed work on correcting the book of Menelaus. Menelaus's commentary on the Spherical consists of three parts, the pamphlet of which contains 31 geometric names. Scholars of a later time expressed

ISSN: 0010-8189

(C) CONVERTER 2021

www.converter-magazine.info 
a number of opinions about the number of sentences in the treatise of Abu Nasr. Some scholars say that the sentences in Abu Nasr's work are 25, 39, while others confirm that it is 24. The group of scholars has concluded that the number of sentences in Abu Nasr ibn Iraq's work is 85. The following opinion is also confirmed by Nasir ad -Din Tusi (1201-1274). Nasir ad-Din at-Tusi recompared all copies of the works of the scholars who reformed the work of Menelaus. Since the opinions of scholars did not coincide with each other, it was decided that Abu Nasr was among those who came to this conclusion. Nasir ad-Din at-Tusi completed his treatise on this subject in 663 AH, in Shaban / 1965, in August.

According to Abu Nasr ibn Iraq, they play an important role in the conditions created for scholars of public administration and the Academy of Khorezm Ma'mun.

Beruni pays special attention to emotional cognition. He writes: "There are many areas of knowledge, and since the human intellect joins it as it develops, this indicates that people strive for science, respect it, respect scientists." Regarding the cognition of the unknown principles of reality, he says: "There is a way of all events that must be cognized, through which knowledge can be achieved."

The encyclopedic book of Abu Raikhan Beruni "Monuments of ancient peoples" [2] can be regarded as a classic encyclopedic work devoted to the analysis and generalization of the events of the last 5000 years of human history. In this book, the great thinker spoke about his scientific and philosophical research and the methods used in the process of writing a work, and wrote: It is determined only by following the "People of the Book" and various clergy, people of different professions and beliefs who follow these (beliefs), and their understanding is always based on this. Then it becomes known by comparing the words and beliefs they cite to prove it "[2, p. 406].

\section{RESULTS.}

In philosophy, the ways and methods of cognition of the Universe were developed, and this is reflected in the methodology (doctrine of methods). Abu Raikhan Beruni discusses social philosophy from the point of view of ways and means of studying man and society [31, p. 56]. Abu Raikhan Beruni emphasizes that the worldview was formed as a result of an evolutionary process.

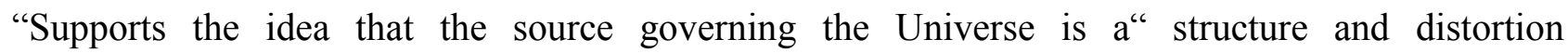
"contradiction" [2, p. 26].

At the same time, Beruni argues that the force that leads the world to social development is not contradictions and contradictions, but compromise and consensus at different social levels. "How can you believe that the contradiction of which is obvious?" [1, p. 99], the thinker points to the growing need for changes in processes free from contradictions. Throughout his career, the scientist was interested in issues of public life, expressed his philosophical views in "India", "Monuments of ancient peoples."

Abu Raikhan Beruni developed the philosophical ideas of the thinkers of Central Asia and the East. In particular, in his work "Monuments of ancient peoples" he tried to solve the problem of human life on a scientific basis. The importance of the geographical factor in the life of society and people has shown its influence on social phenomena. He explained the differences between Muslim and Hindu traditions by geographic conditions and even linked the differences between languages to geographic factors. According to him, the path to philosophy goes through the natural sciences,

ISSN: 0010-8189

(C) CONVERTER 2021

www.converter-magazine.info 
which allow a deeper understanding of being. In general, Beruni complements the definition of philosophy as a science that cognizes the essence of being. He also agreed with the opinion of Abu Mashar al-Bali that "Nature is stronger than all" [1, p. 44]. Scientists of the East and West have made a worthy contribution to the formation and development of the world socio-philosophical doctrine. In certain periods of social development, the countries of the East were in the lead. It is theoretically wrong to unilaterally exaggerate or discriminate against the role of the peoples of Asia and Europe in the development of world philosophy. Any science by its very nature is universal. Every nation on Earth, no matter how big or small, contributes to its development.

Abu Raikhan Beruni laid the foundations of true natural science in the context of the medieval Eastern awakening, he put forward such amazing scientific and hypothetical ideas in various fields of natural science of his time that centuries later they found their confirmation in European science. It should be noted that the works of Beruni also reflect deep social, scientific and philosophical considerations and generalizations associated with his natural science views. Based on the scientific and philosophical teachings of Farobi, he considers Allah to be the root cause of everything. He understands that God is the creator of everything. But Beruni gives nature the right to develop and change everything that comes from the root cause. According to his teaching, everything in nature is created on the basis of natural laws, nature has its own natural power, under the influence of which processes of continuous movement, change, growth, development, formation, decay, destruction occur in nature. ... From this we can conclude that Beruni was in a position close to deism in his scientific and philosophical views. He talks about the literature of the material world.

\section{CONCLUSION.}

The socio-political views of Abu Raikhan Beruni are imbued with humanitarian ideas. $\mathrm{He}$ describes man as the noblest being. He emphasizes that a person should not live only for himself, people should help each other. According to him, the differences between people are more external, they have something in common in the internal structure and organization.

Beruni believes that the development of the country, the well-being of the people is inextricably linked with the development of science. He wrote: "Every scientist should base his discussion on practice, have a clear goal in his research, work tirelessly, seek and correct mistakes, and fight all kinds of fabrications and superstitions in the name of truth in science." He strongly condemns the wars that are destroying humanity, fights for the peoples to live in friendship, unity and union in the country, and calls for peace.

After the establishment of Islam in Movarounnahr, on the one hand, various religious teachings arose, in particular the Kalam schools, in the 9th-12th centuries in Central Asia, the main attention was paid to the sciences of tafsir, hadith and fiqh, on the other. On the other hand, the development of Islamic science in the region served as a key factor for its spread. The teachings of Sufism, deeply penetrated into the social and spiritual life of the Muslim East, had a great positive impact on the development of science, culture and literature. Since the 11th century, almost all influential poets and writers, thinkers and scientists of the East have fed on mysticism and were inspired by its ideas of humanity and justice. In this regard, the famous scientist E. E. Bertels noted: "Without studying mystical literature, it is impossible to get an idea of the cultural life of the medieval Muslim East, without knowledge of this literature it is difficult to understand the East."

ISSN: 0010-8189

C CONVERTER 2021 
myself "[p. 17 544]. The study of the scientific heritage of Abu Raikhan Beruni makes it clear that the scientist recognizes observation, which is the first stage of scientific knowledge, and also raises observation to the level of active experiments, which he widely used in his scientific and creative activities.

\section{REFERENCES:}

1. Abdullaev I. Poetry of Arabic graphics in Central Asia and Khorasan of the 10th century. early XI v. - Tashkent: Fan, 1984.

2. Abu Raikhan Beruni. Monuments of the past generations // Selected productions. Vol. 1. Tashkent: Fan, 1957.

3. Abu Raikhan Beruni. Selected productions. In 6-t. T. 3. - Tashkent: Fan, 1963.

4. Abu Raikhan Beruni. Collection of information for the knowledge of jewelry (Mineralogy) - Moscow: 1963.

5. Abu Raikhan Beruni, India II, t.-Tashkent, 1965.

6. Abu Raikhan Beruni. Determination of granite places to clarify the distance between settlements. Geodesy T. III. - Tashkent: Fan, 1966.

7. Abu Raikhan Beruni. Selected productions. Volume VI.-Tashkent, 1979.

8. Abu Raikhan Beruni. Selected works. Volume 1 - Tashkent: Fan, 1968.

9. Abdullah-zadeh X.F. History of astronomy in medieval Khorasan and Maverannaksra (XI XU centuries): Author's abstract. dis .... doc. ist. the science. - Dushanbe, 1990.

10. Abdukhalimov B. Bayt al-Hikma and scientific works of Central Asian scientists in Baghdad (exact and natural sciences in the 9th-11th centuries). - Tashkent: Tashkent Islamic University. - 2004.

11. Anonymous Arab XI century. -Moscow: Eastern Literature, 1960.

12. Beruni's ten questions on the book of Aristotle "Heaven and the Universe" and the answers to them by Ibn Sina // From the history of advanced socio-philosophical thought in Uzbekistan. Tashkent: Fan. 1959 g.

13. Ten questions of Beruni on the book of Aristotle "Heaven and the Universe" and the answers to them by Ibn Sina // From the history of advanced social and philosophical thought in Uzbekistan. -Tashkent: Fan. $1959 \mathrm{~g}$.

14. Akhmedov A. Al-Khorezmi - astronomer and geographer // Earth and Universe. No. 6. Moscow: 1983.

15. Barthold V. Muslim culture // Barthold V. Works. T. IV. - M.: 1966.

16. Bakhadirov R.M. From the history of the classification of sciences in the Srenevian Muslim East. - Tashkent: Fan, Academy, 2000 .-- 126 p.

17. Bertels E. Sufism and Sufi Literature - M .: Nauka, 1995.

18. Bulatov M.S. Ulugbek Observatory in Samarkand // Historical and Astronomical Research. Issue XVIII. - Moscow: 1986.

19. Bulgakov P.G. Ibn Sina's contribution to practical astronomy // Abu Ali ibn Sina. On the occasion of the 1000th anniversary of his birth. - Tashkent: Fan, 1980.

20. Bulgakov P.G., Akhmedov A.A. Astronomy in Central Asia in the $1 \mathrm{X}$ - XU centuries. // Research on the history, history of science and culture of the peoples of Central Asia. - Tashkent: Fan, 1993.

ISSN: 0010-8189

(C) CONVERTER 2021 
21. Bulgakov P.G. Rumi Kazi-zade. Commentary on "The Constituents of Astronomy" by Chagmini. Introduction, translation from Arabic and comments of Corresponding Member A.N. Roose P.G. Bulgakov. - Tashkent: Fan, 1993.

22. History of the cultural life of Turkestan. T. II. Part 1. - Moscow: 1963.

23. Irisov A. Wisdom of Abu Raykhon Beruni. -Tashkent: Young Guard, 1973.

24. Ibn Sina. Danish name. - Dushanbe.: 1957.

25. Ibodov Yu.Kh. Philosophical views of the Renaissance encyclopedists in Central Asia and their discoveries in the field of science. - Tashkent: Mevrius, 2009.

26. Ibodov J.Kh., Matvievskaya G.P. Place of Ahmad al-Fergani in the history of mathematics and astronomy. - Tashkent: Istiklol, 1998.

27. Young people about the scientific heritage of our ancestors. - Tashkent, 2008.

28. Zokiy Salih. Osori Bakia, 1 t. Istanbul printing. 1329. Institute of Oriental Studies named after Abu Rayhon Beruni of the Academy of Sciences of the Republic of Uzbekistan. 18464 position digital source.

29. Jalolov G. Beruniy and astronomical science. - Tashkent: Fan, 1950.

30. Karimov I.A. High spirituality is an invincible force. - Tashkent: Manaviyat, 2008.

31. Karimov I., Valieva S., Tulenova K. Social philosophy (methodological guide). Tashkent: Fan, 2008.

32. Karimova S.Yu. The role of scholars of Maverannaksra and Khorasan in the development of chemistry and pharmacology in the medieval East (According to written sources of the 9th - 11th centuries): Author's abstract. dis ... .doc. ist. the science. - Tashkent: 2001.

33. Krachkovsky I. Arabic geographical literature // Krachkovsky I. Izbr. hair. T. IV. - M.-L., 1957.

34. Lunin B.V. Bibliographic index of Soviet literature about Abu Raikhan Beruni and the publication of the texts of his works (1918-1972) // State collection for the 1000th anniversary of the birth of Beruni. - Tashkent: Fan, 1973.

35. Lunin B.V. The life and works of ibn Sina in national science // Abu Ali ibn Sina. On the occasion of the 1000th anniversary of his birth. - Tashkent: Fan, 1980.

36. Matvievskaya G.P. The doctrine of number in the medieval Bliném and the Middle East. Tashkent: Fan, 1967.

37. Matvievskaya G.P. Development of research in Europe in the 17th century. - Tashkent: Fan, 1971.

38. Masharipova G.K. The influence of the natural science heritage of the scientists of the Khorezm Academy of Mamun on the development of social and philosophical thinking. (Monograph). - Tashkent: "Navruz", 2019.

39. Masharipova G.K. Great discoveries of the Middle Ages - the contribution of Khorezm mathematicians to the development of science. (Monograph). - Tashkent: "Navruz", 2021.

40. Muminov I. Place and role of Amir Temur in the history of Central Asia. T:. 1968 year

41. Omar Khayyam. Treatises. - Moscow: Gost.lit, 1961.

42. Rozhanskaya M.M. Mechanics of the Middle East East. - Moscow: 1976.

43. Rosenfeld B., Matvievskaya G. Mathematics and astronomy of the Muslim Middle Ages and their works (VIII-XVII centuries). Book 1. - M .: 1982.

ISSN: 0010-8189

(C) CONVERTER 2021 
44. Rosenfeld B.A. An attempt at quadratic interpolation by Abu-r-Raikhan al-Biruni // Historical and mathematical research. - Moscow, 1959. - Issue. XII.

45. Rosenfeld B.A. Arab and Persian physical and mathematical textbooks in the libraries of the Soviet Union // Physical and mathematical sciences in the countries of the East. - Moscow: Science, 1966.

46. Rosenfeld B.A. About Rabataks Ibn Sini in Mathematics and Astronomy / Abu Ali Ibn Sina. On the occasion of the 1000th anniversary of his birth. - Tashkent: Fan, 1980.

47. Semenov A.A. Biruni - an outstanding scientist of the Middle Ages // Biruni - a great scientist of the Middle Ages. - Tashkent: Fan, 1950.

48. Tuychiev B. Scientific and philosophical correspondence between Beruni and Ibn Sina. Tashkent: Ijod Print, 2020.

49. Usmonov T. Place of Beruni in the history of physics. - Tashkent: Fan, 1977.

50. Philosophy: Encyclopedic Dictionary. - Tashkent: Shark, 2004.

51. Pharaoh. The city of noble people. - Tashkent: Abdullah Kodiri National Heritage Publishing House, 1993.

52. Sharipov A. Humanistic views of Beruni // Important stages in the history of socio-ethical and humanistic thought in Uzbekistan. - Tashkent: Philosophy and Law, 2007.

53. Sharipov A. D. An excellent example of Beruni. - Tashkent: Fan, 1972.

54. Shermukhamedova N. Philosophy. -Tashkent: Fan, 2014.

55. Khalidov A. Arabian manuscripts and the Arabian manuscript tradition. - M .: 1985.

56. Khairullaev M.M. The first culture of the Renaissance in Central Asia. - Tashkent: Fan, 1994.

57. Ksolidov A.B., Erman B.T. Introduction to "India" Beruni // India. T. II. -Moscow, 1963.

58. From the history of the peoples of Central Asia. - Tashkent, 1990.

59. Khikmatullaev H. Treatise of Abu Ali ibn Sina "Medicines of the heart". - Tashkent: Fan, 1966.

60. Rodet L. L'algebred'Alkarizmiet les methodesindiens et grecques. Journ. as. ser. 7. T. 11. 1878.

61. Rudloff G., Hochheim A. DieAstronomie des Mahmud ibnMuhammedibn 'Omar alCagmini // Zeitschrift der DeutschenMorgenlandischenGeselschaft, Bd.47, 1893.

62. Sayili A. AbdulhamidibnTurk'un «KatisikDenklemlerdeMantikiZaruretler» adliyazisivezamanincebri (Logical nacassities in mixed equations by 'Abd al-Hamid ibn Turk and thealgebra of his time), Text in turkish, english and arabic, Turk TarihKurumuJayinlardan. Ankara. 1962. VII. Seri. 41.

63. Sayili A. The observatory in Islam. -Ankara, 1960.

64. Sarton G. Introduction tothehistori of science, vol. I-III. - Baltimore. 1927-1948.

65. Sarton G. Adrian von Romen's commentary on Al-Khowarizmi (1598). Isis. vol. 21. 1934.

66. Sezgin F. Geaschichte des arabischenSchrifltums. Bd. V. - Leiden, 1974. - P. 45-52; Sezgin F., GAS, Bd V. - Leiden. 1974. Bd. VI. 1978.

67. Simon M. ZuHwarizmi'shisabalgabrwalmuqabala, ArchivScripta. math. und phys. Reihe 13. Bd. 28. 1919.

ISSN: 0010-8189

(C) CONVERTER 2021 
68. Suter H. RezinsionRushka, Zuraltestenarabishen Algebra, Archiv s. math. uphus. Bd.28, 1919. - 232 p.; Suter H. DieMathematiker und Astronomen der Araber und ihreWerke, Leipzig. 1900 .

69. Wallis J. De postulatoquintoetdefinitionequinta lib. 6 Euclidis; disceptatiogeometrica. Opera mathematica. - Oxoniae. 1693. T. 2.

70. Wiedemann E. Uberein von Avicenna hergestelltesBeobachtungsinstrument.»Zeitschr., fur Instrumentenkunde». Bd. 45. 1925.

71. Wiedemann E. EinleitungzudemastronomischenTeil des Kitab al Schifa (Werk der Genesung ) von IbnSina , «Sitzungsber, d. phys.-med. Soz. In Erlangen»- Bd. 58-59, 19261927.

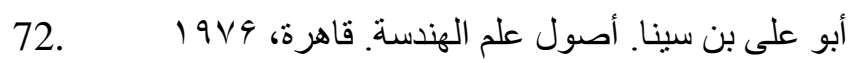

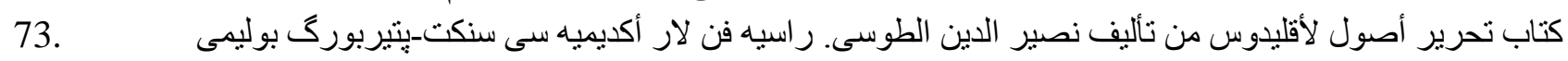

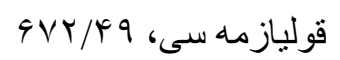

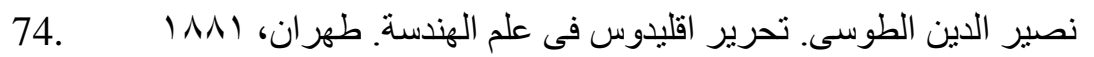

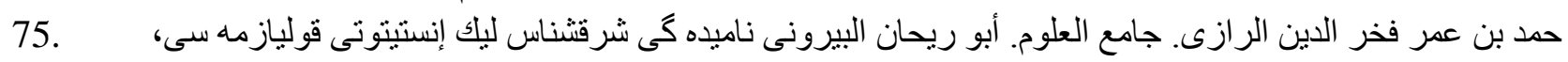

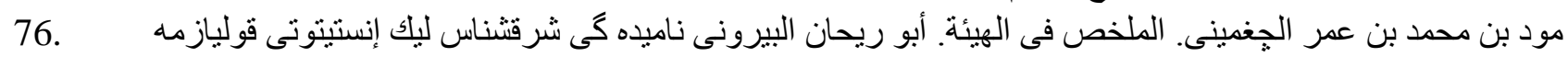

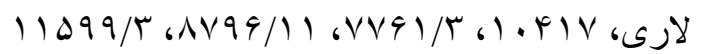

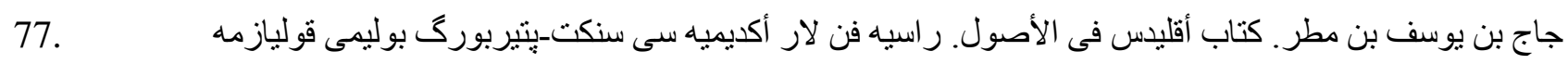

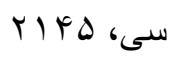

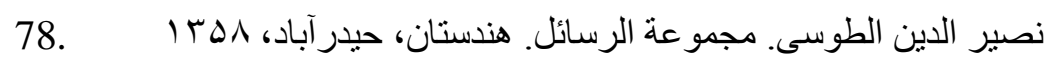

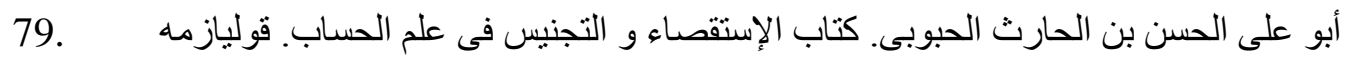

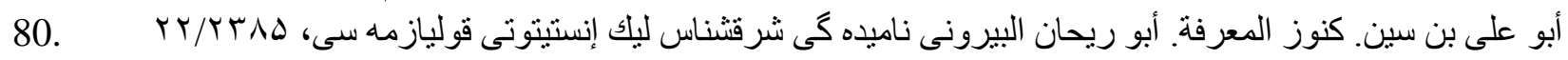

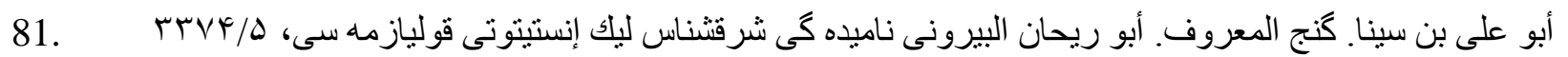

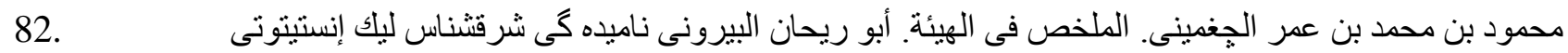

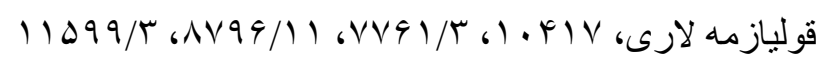

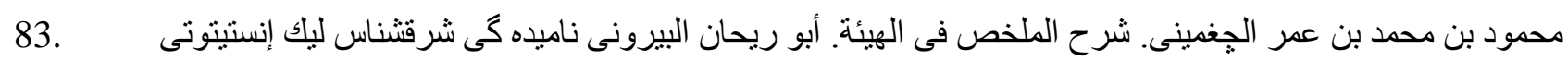

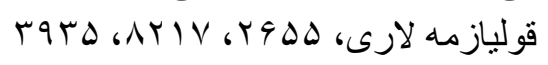

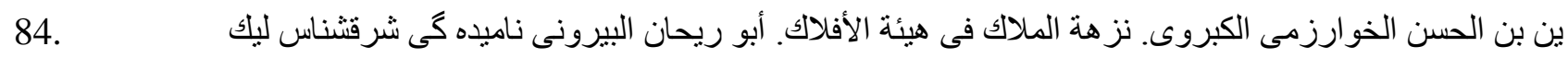

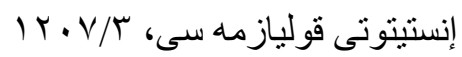

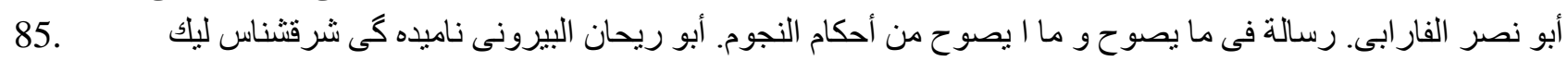

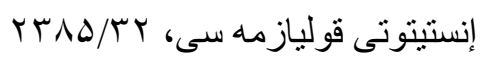

ISSN: 0010-8189

(C) CONVERTER 2021 